\title{
血液透析に伴う脳血管障害 一脳梗塞の病型と背景因子の検討一
}

\author{
川畑信也鶴田良成* 桐生 宏司* 桜内靖浩* \\ 成田 眞 康** \\ 成田記念病院神経内科 同腎臓内科* 同内科**
}

key words：血液透析，高血圧，脳血栓，脳梗塞，脳塞栓

〈要旨〉

血液透析に伴う脳梗塞の臨床像を脳出血と比較し検討した。対象は脳梗塞 9 例 (平均発症年齢 66.3 歳, 平均透析 期間 77.2 か月）で, 比較対照群として脳出血 21 例（同 63.1 歳，56.0 か月）を用いた。脳梗塞群の臨床像を脳出血 群と比較すると, (1) 脳梗塞の急性期の死亡率は低い (22.2\%), (2) 脳梗塞では心疾患歴が高い, といった特徵が挙 げられる. 脳梗塞の臨床病型の特徵として, (1) 頭蓋内主幹動脈に血栓性あるいは塞栓性の閉塞が起こりやすく, 中 等大から広範囲に及。ぶ梗塞巣が出現しやすい. 一方, ラクナ梗塞は少ない. (2) 多様な発現機序に基づいた脳梗塞が みられる. (3) 血行力学的な灌流障害に基づく脳梗塞の頻度が高い. とくに, 血液透析患者では血行力学的な機序に 基づく脳梗塞が発現しやすい.

\section{Cerebrovascular disease associated with maintenance hemodialysis -A study of the clinical subtypes and background factors of brain infarction-}

Nobuya Kawahata, Yoshinari Tsuruta*, Kohji Kiryu*, Yasuhiro Sakurauchi*, Masayasu Narita** Department of Neurology, Nephrology*, and Internal Medicine**, Narita Memorial Hospital

We evaluated the clinical subtypes and background factors of stroke in nine hemodialyzed patients with brain infarction in comparison with 19 hemodialyzed patients with brain hemorrhage. Mean age at the time of occurrence of brain infarction tended to be higher than the age at the time of occurrence of brain hemorrhage ( 66.3 years vs 63.1 years). The mean interval between the start of hemodialysis therapy and the occurrence of stroke was also longer than among the patients with brain hemorrhage ( 77.2 months vs 56.0 months). The brain infarction mortality rate was lower $(22.2 \%)$ than that of brain hemorrhage $(76.2 \%)$. According to the clinical classification of the National Institute of Neurological Disorders and Stroke, five patients had massive atherothrombotic infarction in the middle or posterior cerebral artery and four patients had cardioembolic infarction. There were no cases of lacunar infarction in our case series. Three of the five patients with atherothrombotic infarction had massive infarctions produced by hemodynamic mechanisms. Background factors consisted of hypertension in five patients $(55.6 \%)$, heart disease in five(55.6\%), diabetes mellitus in four $(44.4 \%)$, and arrhythmia in one (11.1\%). Heart disease was noted in two patients with cardioembolic infarction and three patients with atherothrombotic infarction. There were significant differences between the frequency of heart disease and cigarette smoking in the hemodialyzed patients with brain infarction and brain hemorrhage.

川畑＼cjkstart信也 成田記念病院神経内科厂４41 豊橋市白河町78（0532-31-2167）

〔受付：平成 7 年 2 月 16 日，受理：平成 7 年 8 月 21 日〕 


\section{緒言}

非透析患者にみられる脳血管障害では，発症年 齢の高齢化などに伴う脳梗塞の増加と高血圧をは じめとする危険因子の適切な治療を反映した脳出 血とくも膜下出血の減少傾向がいわれてきてい る.一方, 血液透析に伴う脳血管障害では, 脳出 血の占める割合が圧倒的に高くその生命予後も不 良とされる ${ }^{1,2)}$.この脳出血の優位性と対照的に脳 梗塞のみられる頻度は非常に低い33. さらに脳出 血の発症要因あるいは背景因子として, 高血圧や 全身性または局所性 heparinization, 抗血小板薬 の使用, 頭部外傷, Ca-P 代謝異常に伴う異所性石 灰化, 血小板凝集能の低下, 脳血管アミロイド沈 着などが挙げられている ${ }^{3}$ が, 血液透析に伴う脳 梗塞の背景因子については不明な点が多い. 現在 までに血液透析に伴う脳梗塞を対象とする臨床的 な検討は極めて少ない ${ }^{4,5)}$. 今回, 血液透析に伴う 脳梗塞の病態, とくに背景因子と病型について検 討を加えたので報告する.

\section{対象と方法}

1986 年 1 月から 1994 年 7 月までに成田記念病 院血液透析センターに通院または入院していた血 液透析患者に発症した脳血管障害 34 例のなかで 脳梗塞をきたした 9 例を対象とした，脳梗塞の診 断は頭部X線 CT と MRI に, 閉塞血管の同定は 脳血管 DSA または MR アンギオグラフィーに よって診断した。一過性脳虚血発作 TIA のみの 症例, 脳血管障害を疑わせる意識障害や一過性の 神経脱落徴候がみられるが症状の永続性に欠ける
症例, 画像診断で神経徴候に該当する責任病巣が 同定できない症例は検討から除外した。臨床的な 事項の検討では同期間内にみられた脳出血 21 例 を比較対照群として用いた。発症年齢や透析期間, 脳血管障害の背景因子(高血圧, 糖尿病, 心疾患, 血清脂質異常, 不整脈, 常習性の喫煙 (5 本/日以 上）と飲酒（日本酒換算で 1 合/日以上)，TIAの 既往)，病型などについて検討した。

病型は, NINDS から出された脳血管障害の分 類第III版 ${ }^{6)}$ に準拠し, 臨床病型では, (1) 頭蓋外や頭 蓋内主幹動脈の粥状硬化性病変を基盤に発症する アテローマ血栓性脳梗塞, (2) 心疾患に伴う心内血 栓や末梢静脈血栓が心内シャントを経て大動脈系 へ流出する奇異性塞栓による心原性脳塞栓症, (3) 細動脈の閉塞によって基底核や深部白質, 橋底部 などの脳深部に最大径 $15 \mathrm{~mm}$ 以下の小梗塞をみ られるラクナ梗塞の 3 型に, 発現機序では, (1) 血 栓性, (2) 塞栓性, (3) 血行力学性の 3 型に分け, 著 者の 1 人 (NK) によって病型が決定された. 生命 予後は発症 30 日目の生死によって決定した。

年齢などは平均值士標準偏差で示した。平均值 の検定は，対象が少数なのでノンパラメトリック 検定を選択し，独立した 2 群間では Wilcoxon 順 位和検定に，百分率の検定は $\lambda^{2}$ 検定に拠った。 危険率 0.05 以下の場合に有意差ありと判断した。

\section{結果}

1. 発症年齢や基礎疾患などの検討（表）

脳梗塞 9 例の発症年齢は 49 歳から 80 歳の間に 分布し平均 $66.3 \pm 9.7$ 歳であった。脳出血 21 例の

表 脳梗塞をきたした 9 例の背景因子

\begin{tabular}{|c|c|c|c|c|c|c|c|c|c|c|c|c|c|}
\hline \multicolumn{2}{|c|}{ 年齢 } & 性 & 基礎疾患 & 機序 & 分類 & 病栄部位 & 高血圧 & 心疾患 & 不整脈 & $\begin{array}{l}\text { 透析 } \\
\text { 期間（月） }\end{array}$ & $\mathrm{TC}$ & $\mathrm{Ht}$ & 生命予後 \\
\hline 1 & 68 & 男 & 糖尿病 & 塞栓 & 心原性脳塞栓 & 後大脳動脈 & + & + & + & 60 & 156 & 28.7 & 生存 \\
\hline 2 & 63 & 女 & 慢性腎炎 & 塞栓 & 心原性脳塞栓 & 中大脳動脈 & - & - & - & 145 & 105 & 20.4 & 死亡 \\
\hline 3 & 49 & 男 & 糖尿病 & 塞栓 & 心原性脳塞栓 & 脳底動脈 & - & - & - & 116 & 184 & 31.2 & 生存 \\
\hline 4 & 63 & 男 & 糖尿病 & 塞栓 & 心原性脳塞栓 & 中大脳動脈 & + & + & - & 67 & 207 & 39.7 & 生存 \\
\hline 5 & 56 & 男 & 慢性腎炎 & 血行力学 & アテローマ血栓 & 後大脳動脈 & + & + & - & 212 & 177 & 29.1 & 生存 \\
\hline 6 & 76 & 女 & 糖尿病 & 血行力学 & アテローマ血栓 & 中大脳動脈 & + & + & - & 1 & $?$ & 28.1 & 死亡 \\
\hline 7 & 72 & 男 & 慢性腎炎 & 血行力学 & アテローマ血栓 & 中大脳動脈 & + & - & - & 77 & 149 & 24.9 & 生存 \\
\hline 8 & 70 & 男 & 慢性腎炎 & 血栓 & アテローマ血栓 & 中大脳動脈 & - & + & - & 1 & 198 & 22.5 & 生存 \\
\hline 9 & 80 & 男 & 慢性腎炎 & 血栓 & アテローマ血栓 & 後大脳動脈 & - & - & - & 15 & 184 & 27.0 & 生存 \\
\hline
\end{tabular}

TC：血清総コレステロール Ht：ヘマトクリット 


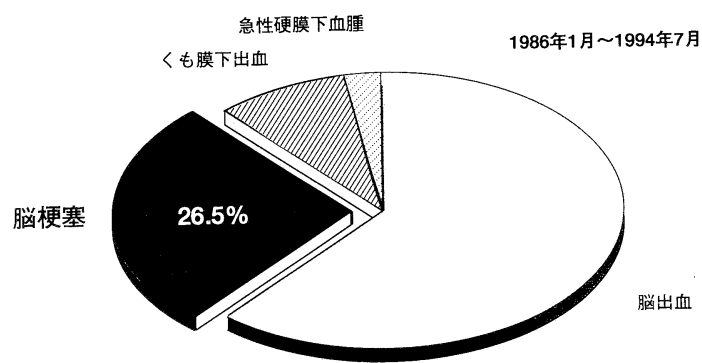

図 1 血液透析に伴う脳血管障害 34 例の病型

平均発症年歯椧 $63.1 \pm 9.3$ 歳で, 脳梗塞群の発症 年齢は脳出血群に比し高い傾向にあったが統計学 的な有意差はみられなかった $(Z=-0.77, \mathrm{p}=$ $0.44)$. 男性 7 名 (平均発症年齢 $65.4 \pm 10.4$ 歳), 女性 2 名 (69.5 19.2 歳)である。透析導入から脳 梗塞発症までの期間は，1 1 月から 212 か月に分 布し, 平均 $77.2 \pm 70.9$ か月であった. 脳出血群に おける同期間は平均 $56.0 \pm 44.6$ か月で, 脳梗塞群 で透析期間がやや長期に及ぶ傾向がみられたが, 統計学的な有意差には至らなかった $(Z=-0.43$, $\mathrm{p}=0.67)$. 血液透析導入の原因となった基礎疾患 は慢性腎炎 5 例，糖尿病性腎症 4 例である。

2 . 病型と予後

図 1 に脳血管障害 34 例の病型別頻度を示す.脳 出血が 21 例 $(61.8 \%)$ と最も多く, 以下，脳梗塞 9 例 $(26.5 \%)$, くも膜下出血 3 例 $(8.8 \%)$, 急性 硬膜下血腫 1 例 (2.9\%) であった。臨床病型から みた脳梗塞 9 例の内訳は, アテローマ血栓性脳梗 塞 5 例, 心原性脳塞栓症 4 例で, ラクナ梗塞はみ られなかった。一方，発現機序からみると，アテ ローマ血栓性脳梗塞を示した 5 例の内訳は血栓性 2 例, 血行力学性 3 例であった. 血行力学性 3 例 の原因として, 症例 5 と 7 では降圧剤による過剩 な血圧低下, 症例 6 では透析中の急激な血圧低下 が想定された．透析導入の基礎疾患と病型との間 には一定の傾向はみられなかった。

脳梗塞群の死亡は 2 例で急性期の死亡率は $22.2 \%$ であった. 脳出血群の死亡率は $76.2 \%$ に及 び, 脳梗塞群の急性期の生命予後は脳出血群に比 し有意に良好であった $\left(\lambda^{2}=5.56, \mathrm{p}=0.02\right)$. 死 因をみると，症例 2 は吐血による窒息と血圧低下

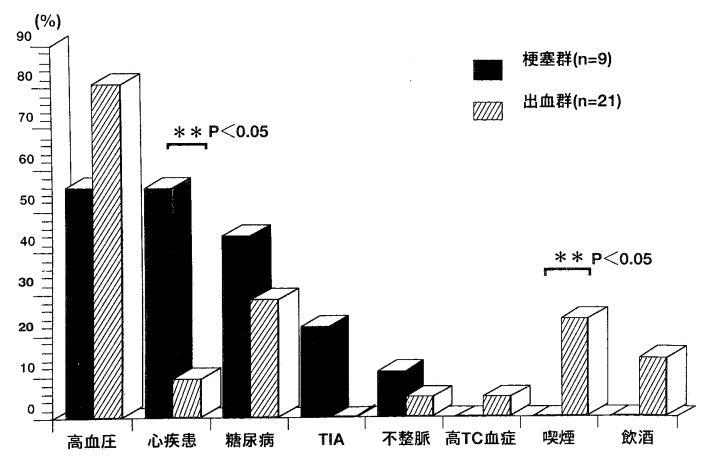

図 2 脳梗塞群と脳出血群における危険因子の比較

が出現し, さらに多藏器不全が加わり死亡した。 症例 6 は第 9 病日に原因不明の急激な血圧低下が 出現し死亡した。

3 . 背景因子の検討

脳血管障害の背景因子（図 2 ）を検討すると， 脳梗塞群では高血圧 5 例 (55.6\%)，心疾患 5 例 (55.6\%) でその内訳は連合弁膜症 3 例，陳旧性心 筋梗塞 1 例, 狭心症 1 例, 糖尿病 4 例 $(44.4 \%)$, TIA 2 例 $(22.2 \%)$, 不整脈 1 例 (11.1\%) であっ た.TIA は症例 4 と 8 にみられ，症例 4 は脳血管 造影で両側内頸動脈の狭窄があり両側内頸動脈内 膜剝離術が施行されていた，高脂血症と喫煙，飲 酒はみられなかった。一方，脳出血群では高血圧 17 例 $(81.0 \%)$, 糖尿病 6 例 $(28.6 \%)$ ，心疾患 2 例 $(9.5 \%)$, 不整脈 1 例 $(4.8 \%)$, 高脂血症 1 例 (4.8\%), 喫煙 5 例 (23.8\%), 飲酒 3 例 (14.3\%) であった。TIA の既往はみられなかった。脳梗塞 群で心疾患歷が有意に高かった $\left(\lambda^{2}=7.78, \mathrm{p}=\right.$ $0.02)$.

脳梗塞群の発症 1 か月以内の血清コレステロー ル (TC) 值の平均は $170.0 \pm 32.6 \mathrm{mg} / \mathrm{d} l$ であっ た. 脳出血群の平均 $146.6 \pm 28.5 \mathrm{mg} / \mathrm{d} l$ と比較す ると, 脳梗塞群では正常範囲内に位置する傾向に あった（ $Z=-1.9 ， \mathrm{p}=0.06)$ 。また，低 TC 血 症 $(150 \mathrm{mg} / \mathrm{d} l$ 末満 $)$ がみられる頻度は，脳梗塞 群で $25.0 \%$, 脳出血群で $56.3 \%$ あった $\left(\lambda^{2}=\right.$ $1.03, \mathrm{p}=0.31)$.

脳梗塞発症前に施行された 3 度の採血による血 小板数は平均 $17.6 \pm 5.0$ 万 $/ \mathrm{mm}^{3}\left(10.7\right.$ 万 $/ \mathrm{mm}^{3}$ 


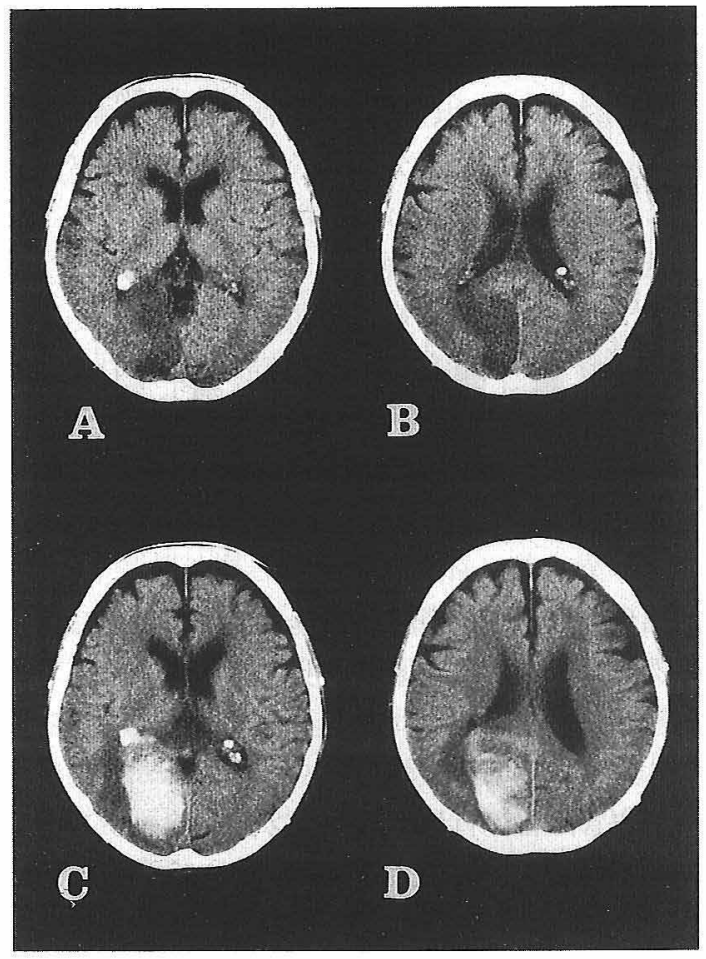

区 3 症例 1 の頭部 CT 像。 A，B：第 2 病日の 単純 CT 像。右後頭葉全域に及引低吸収域 がみられる。C，D：第 17 病日の単純 CT 像。右後頭葉全域に拡大した出血性梗塞が みられる（向かって左側が右大脳半球を示 寸，以下同様)。

から 22.9 万 $/ \mathrm{mm}^{3}$ に分布)，へモグロビン は平均 $9.3 \pm 2.2 \mathrm{~g} / \mathrm{d} l(6.6 \mathrm{~g} / \mathrm{d} l$ 加ら $14.2 \mathrm{~g} / \mathrm{d} l)$, 八 マトクリット $(\mathrm{Ht})$ は平均 $28.0 \pm 5.6 \%(20.4 \%$ から $39.7 \%$ )であった。脳出血群の平均血小板数 $21.7 \pm 8.2$ 万 $/ \mathrm{mm}^{3}$, HB $8.5 \pm 1.3 \mathrm{~g} / \mathrm{d} l$, Ht $25.8 \pm$ $4.5 \%$ と比較していずれも有意な相違はみられな かった。

\section{4. 代表例の呈示}

症例 $1 ： 68$ 歳，男性，心原性脳塞栓症をきたし た症例。糖尿病性腎症によって透析が導入され 5 年の透析歴あり。連合弁膜症 (AR, MR, TR) と 一過性心房細動，高血圧の治療中であった。1992 年 7 月 21 日午後 4 時 30 分, 突然右側頭部痛と左 視野の視力低下を自覚し入院となった。神経学的 には，意識は清明，病棟内で自室に戻れないなど の道順障害が認められた。脳神経では左同名性半

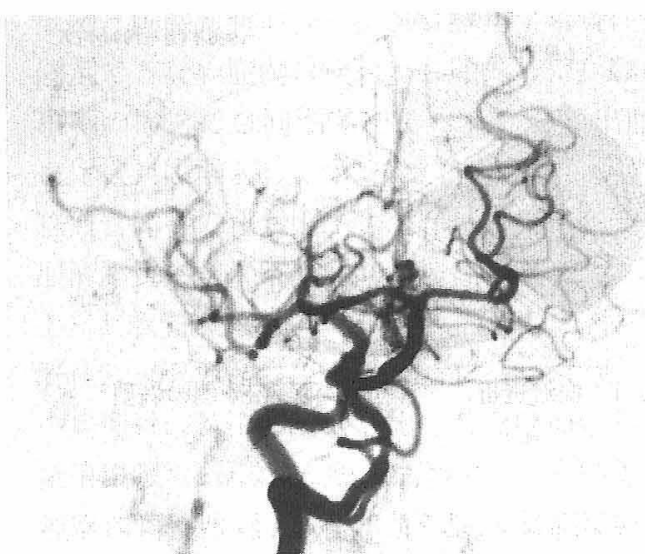

図 4 症例 1 の逆行性右上腕動脈造影 (正面像)。 動脈相にて右後大脳動脈末梢部での造影不 良がみられるが，CT 像でみられた梗塞巣 の責任血管と考えられる後大脳動脈起始部 の閉塞はみられない。

盲がみられた。頭部 CT で右後頭葉全域に及ぶ低 吸収域がみられた(図 $3 \mathrm{~A} ， \mathrm{~B}$ )。脳血管造影では, 右後大脳動脈末梢部に造影不良がみられたが明ら かな閉塞血管は確認できなかった。後大脳動脈起 始部における塞栓性閉塞の再開通現象と診断した (図 4 ).脳梗塞発症後も, ペリンーナトリウム透 析と塩酸チクロピジン $200 \mathrm{mg}$ の経口投与が継続 されていたが，第 17 病日の頭部 CT(図 3 C，D) で，右後大脳動脈領域に広範な高吸收域がみられ 出血性梗塞に移行していた。この時点でメシル酸 ナファモスタット透析への変更と塩酸チクロピジ ンの投与中止が行われた。本例は，連合弁膜症と 一過性心房細動を背景に心原性脳塞栓症をきた し，閉塞血管の再開通現象に伴い出血性梗塞に移 行し,さらにへパリン透析と抗血小板薬投与に よって出血性梗塞が増悪したものと考えられる。

症例 $5: 56$ 歳, 男性, 血行力学的な灌流障害由 来のアテローマ血栓性脳梗塞をきたした症例。慢 性腎炎による 17 年 8 か月の透析歴がみられた。脳 梗塞発症時には CAPD が施行され降圧療法が行 われていた。1992 年 11 月 16 日朝，自宅での血圧 は 130/90 mmHg, 7 時にニコランジル (シグマー ト® ) $5 \mathrm{mg}$, ニソルジピン (バイミカード®) $5 \mathrm{mg}$, 塩酸デラプリル（アデカット®） $15 \mathrm{mg}$ を服用し た. 7 時 30 分通院のために乗っていた電車内でめ 


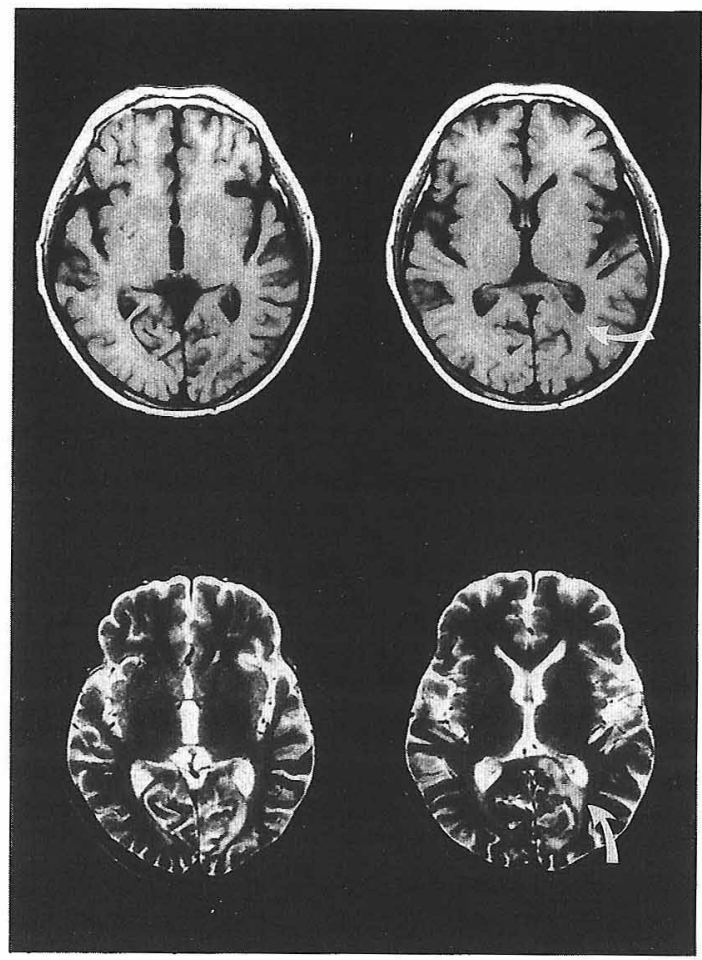

図 5 症例 5 の頭部 MRI. 左後頭葉内側部から左 脳梁膨大部にかけて $T_{1}$ 強調画像 (TR 520 msec, TE $15 \mathrm{msec}$ ) で低信号域, $\mathrm{T}_{2}$ 強調 画像 (TR 2,500 msec, TE $90 \mathrm{msec}$ ) で高信 号域に描出される梗塞巣がみられる(矢 印)。

まい発作が出現し， 8 時に病院で血圧を測定した ところ 100/50 mmHg に低下していた。この時か ら視野狭窄がみられ神経内科に紹介となった。神 経学的には，右視野の不完全な視野障害以外に明 らかな異常はみられない。頭部 MRI で左後頭葉 内側部から左脳梁膨大部にかけて $\mathrm{T}_{1}$ 強調画像で 低信号域, $T_{2}$ 強調画像で高信号域に描出される梗 塞巣が確認された(図 5 の矢印)。MRアンギオグ ラフィーでは, 左後大脳動脈の crural segment $\left(\mathrm{P}_{2}\right)$ での開塞がみられた（図 6 )。本例は，䩑状 硬化性病変によって左後大脳動脈の閉塞がすでに 存在している下に降圧剤による過剩な血圧低下が 加わって脸虚血を生じたものと推測された。

症例 8：70 歳, 男性, TIA を前駆症状としたア テローマ血栓性脸梗塞をきたした症例。1989 年 2 月 10 日午前, 一過性の構音障害と右上肢の脱力が

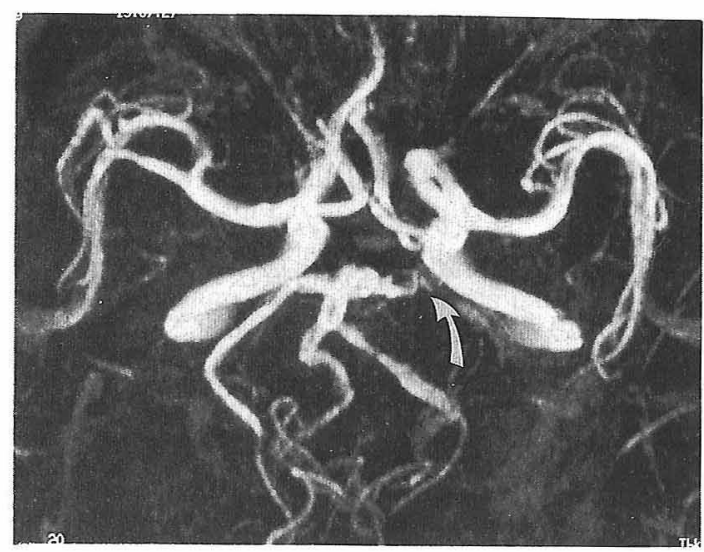

図 6 症例 5 の MR アンギオグラフィー(水平 断). 左後大脳動脈の crural segment $\left(\mathrm{P}_{2}\right)$ での閉塞がみられる (知)。

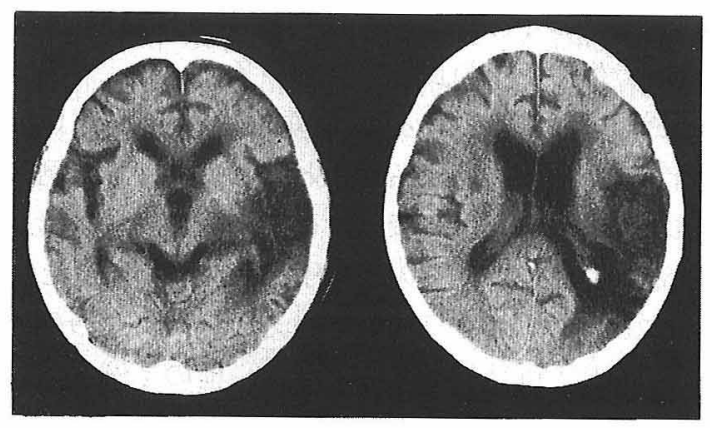

図 7 症例 8 の頭部 CT 像. 左側頭葉底部から頭頂 葉に及ぶ広範な梗塞巣がみられる。

出現したが数分で消失した。2月 16 日，再び発語 障害と右上下肢の脱力が出現し入院となった。神 経学的にはウエルニッケ失語と右上下肢の完全 片麻痺がみられた。頭部 CT にて左側頭葉から頭 頂葉にかけて広範な梗塞巣が確認された（図 7 )。 脳血管造影は施行できなかった。本例は頭蓋内主 幹動脈（左中大脳動脈水平部）の粥状硬化性病変 部における急性閉塞に基づく病態と考えられた。

\section{考察}

血液透析に伴う脳梗塞の臨床像について, 脳出 血群と対比して検討し考察を加えた。まず，脳血 管障害の病型では, 脳出血が全体の $61.8 \%$ を占め 圧倒的に多い点が非透析患者にみられる兴血管障 害と大きく異なる特徴であった。一方，これと対 
照的に脳梗塞の占める割合はわずか $26.5 \%$ にす ぎなかった.“わが国の慢性透析療法の現況”に 報告されている剖検等により確認された死亡原因 分類をみても脳梗塞は脳出血の 3 分の 1 を占める にすぎない，諸家の報告をみても脳出血の優位性 は明らかである ${ }^{8,9)}$ 。慢性透析療法の創設期から, 長期透析患者では動脈硬化症が加速され, 脳を含 めた心血管系の合併症が致死的な経過の要因とな ることが多いといわれる ${ }^{10)}$. 当然, 血液透析患者で は脳血栓が発症しやすいものと予測されるが，現 実には脳梗塞の占める割合は低い. なお, 亀山ら は脳卒中症候を示さない透析患者 71 名で $53.5 \%$ に頭部 MRI で虚血性病変がみられたと報告して いる. 症候性脳梗塞の準供状態とされる無症候性 脳梗塞は予想外に多い可能性が考えられる。

急性期の死亡率をみると, 脳出血と比較して脳 梗塞で生命予後の良好な症例が多かった。一方， 非透析患者にみられる脳梗塞では発症 1 か月以内 の急性期死亡率は $5 \%$ 前後とされる ${ }^{11}$. 少数例の 検討ではあるが，血液透析に伴う脳梗塞も脳出血 ほどではないが，その生命予後は非透析患者と比 較すると必ずしも良好とはいえない. 対象の死因 をみると 1 例は吐血による窒息，他の 1 例は原因 不明の急激な血圧低下が原因となっていた，大血 腫の形成による脳死が直接的な死因となる脳出血 と対照的に, 脳梗塞では必ずしも梗塞病変自体が 直接死因に結びついているわけではなく，合併症 が致死的な経過に関与することが多い. 心血管系 を含めた合併症を予防することによって急性期の 死亡率をさらに低下させることが可能と考えられ た。

臨床病型をみると，アテローマ血栓性脳梗塞が 5 例, 心原性脳塞栓症が 4 例であった. 今回の検 討では対象が 9 例と少ないので，たまたまラクナ 梗塞がみられなかったと考えられるが，血液透析 に伴う脳梗塞の特徵として, 頭蓋内主幹動脈に血 栓性あるい恰塞栓性の閉塞を生じ，中等大から広 範囲に及ぶ梗塞巣が出現しやすい. 第 2 の特徵と して, 多様な発現機序に基づいた脳梗塞の病型が みられたことが挙げられる. 第 3 の特徵として, 血行力学的な灌流障害に基づく脳梗塞が全体の 3
分の 1 にみられた点である. 血行力学的機序によ る脳梗塞は全脳梗塞の $7.7 \%{ }^{12)}$ あるいは $9.6 \%{ }^{13)}$ を占め, その原因として糖尿病性自律神経障害や 過剩な降圧療法による血圧低下，心臓手術に伴う 合併症, 心筋梗塞や不整脈, 内頸動脈の高度な狭 窄や閉塞 ${ }^{13)}$ が挙げられる.しかし, 臨床の場でこの 血行力学的な機序が生じる前後の状況を把握でき ることは極めて稀である。慢性透析患者では, 高 血圧に伴い動脈硬化症が促進されやすい融.さら に，長期にわたる高血圧により脳の自動調節能の

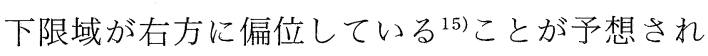
る。これらを背景に透析療法中の急激な血圧低下 や降圧剤の過剩な効果などによって脳の自動調節 能の下限域を超える血圧低下が生じ, その結果, 脳血流の低下を招き脳虚血を生じる可能性が考え られる. 非透析患者に比し血液透析患者では血行 力学的な機序に基づく脳梗塞が発現しやすいこと を強調したい.

脳血栓症の発症因子のひとつに高 Ht 血症が挙 げられる ${ }^{16,17)}$. 老年者 432 例を対象に $\mathrm{Ht}$ と脳梗

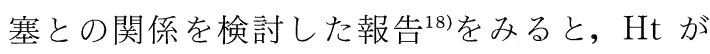
$30 \%$ 以下では脳梗塞の発症はわずか $6.6 \%$ であっ たが, 36\%から 40\%では $18.3 \%, 46 \%$ から $50 \%$ で は $43.6 \%$ にんでいた. Ht の増加は血液粘度の 亢進を招き，脳血流の低下や脳血管の閉塞に繫が る. 血液粘度の低下という視点からみると, 低 $\mathrm{Ht}$ 血症は脳血栓を生じにくい病態と考えられる.今 回の対象も発症前に erythropoietin (rHuEPO) 製剂が投与され Ht が $39.7 \%$ を示した 1 例を除 くと, $20.4 \%$ から $31.2 \%$ の間に分布しいずれの症 例も成人正常值以下に位置していた，脳血管障害 を合併しているか否かにかかわらず慢性透析患者 では慢性貧血が長期にわたり持続している場合が 多い. 著者らは，この低 $\mathrm{Ht}$ 血症が脳梗塞の発現 に対して抑制的に働き，その結果，透析患者全体 として脳梗塞の発症が少ないのではないかと考え ている。むろん，今回の検討では，低 Ht 血症に もかかわらず脳梗塞を発症しており, Ht 以外の 病態が脳梗塞の発症に関与していることは論を待 たない，また，他の背景因子をみると，心疾患が 脳梗塞群で高率にみられた。脳塞栓症の大部分は 
心臓由来とされ, 全脳梗塞に占める心原性脳塞栓 症の頻度は $15 \%$ から $20 \%$ とされる ${ }^{19,20)}$. 今回の検 討で心疾患を指摘されていた患者は，心原性脳塞 栓症の 2 例以外にアテローマ血栓性脳梗塞のなか にも 3 例みられ, 必ずしも心疾患の存在が心原性 脳塞栓症を示唆するわけではなかった.

\section{結論}

1. 血液透析に伴う脳梗塞の頻度は, 脳血管障 害全体の $26.5 \%$ 占めていた。

2. 脳梗塞の急性期の生命予後は, 脳出血と比 べてはるかに良好であるが, 非透析患者の脳梗塞 と比較すると必ずしも良好とはいえない。

3. 多様な臨床病型と発現機序に基づく脳梗塞 がみられる．とくに血行力学的な機序に基づく脳 梗塞は血液透析に伴う脳梗塞の特徵と考えられ た.

\section{文献}

1) Onoyama K, Kumagai H, Miishima $T$, Tsuruda $\mathrm{H}$, Tomooka S, Motomura K, Fujishima $\mathrm{M}$ : Incidence of strokes and its prognosis in patients on maintenance hemodialysis. Jpn Heart J 27 : 685-691, 1986

2) 小穴勝榣, 村上壽治, 和田 司, 後藤康樹, 苗 代 弘, 金谷春之, 伊藤幸夫 : 透析療法下脳出 血一その臨床像と治療上の問題点一. 日本医事 新報 $3520: 27-30,1991$

3）川畑信也：血液透析と脳血管障害.内科 72 ： 501-504, 1993

4）亀山正邦, 阪口勝彦, 西中和人, 辻村崇浩, 宇 高不可思, 伏見尚子：慢性腎透析と脳血管障害 一第 39 回日本透析医学会招待講演より一. 透析 会誌 $27 ： 1363-1371,1994$

5）野田恒彦：透析患者の合併症とその対策. 中枢 神経障害一総論, 脳梗塞。(日本透析医会・合併 症対策委員会編), p1-10, 日本透析医会, 東京, 1994

6) National Institute of Neurological Disorders and Stroke Ad Hoc Committee: Classification of cerebrovascular diseases III. Stroke $21: 637-676,1990$

7）日本透析医学会統計調查委員会：わが国の慢性
透析療法の現況（1993 年 12 月 31 日現在）. p111, 日本透析医学会, 1994

8）小野山薫, 井林雪郎, 藤島正敏：透析患者の脳 卒中. 臨床と研究 $62: 109-115,1985$

9) Iseki K, Kinjo K, Kimura Y, Osawa A, Fukiyama $\mathrm{K}$ : Evidence for high risk of cerebral hemorrhage in chronic dialysis patients. Kidney Int $44:$ 1086-1090, 1993

10) Lindner A, Charra B, Sherrard DJ, Scribner $\mathrm{BH}$ : Accelerated atherosclerosis in prolonged maintenance hemodialysis. N Engl J Med 290：697-701, 1974

11）沓沢尚之：最近の脳卒中一臨床疫学的検討か ら一。脳卒中 $9 ： 473-480,1987$

12) Rosenfeld WE, Lippmann SM, Levin H, Scheinberg P : Hypotension - a cause for ischemic CVA. Neurology $33: 146,1983$

13) Bladin CF, Chambers BR: Frequency and pathogenesis of hemodynamic stroke. Stroke $25: 2179-2182,1994$

14) Vincenti F, Amend WJ, Abele J, Feduska NJ, Salvatierra O Jr: The role of hypertension in hemodialysis-associated atherosclerosis. Am J Med $68:$ 363-369, 1980

15）田川皓一, 川畑信也：臟器循環動態 脳. 高血 圧. 日本臨牀 44 (増刊号)：230-236，1986

16) Kannel WB, Gordon $T$, Wolf PA, McNamara $\mathrm{P}:$ Hemoglobin and the risk of cerebral infarction: the Framingham study. Stroke 3: 409-419, 1972

17) Harrison MJ, Pollock S, Kendall BE, Marshall J : Effect of hematocrit on carotid stenosis and cerebral infarction. LancetII : 114-115, 1981

18) Tohgi H, Yamanouchi H, Murakami M, Kameyama M : Importance of the hematocrit as a risk factor in cerebral infarction. Stroke 9:369-374, 1978

19) Cerebral Embolism Task Force:Cardiogenic brain embolism. Arch Neurol 43:71 $-84,1986$

20）峰松一夫：心原性脳塞栓症の頻度統計. CT, MRI 時代の脳卒中学 日本臨牀 51 (増刊号)： 568-572, 1993 